\title{
Soybean oversowing with Urochloa brizantha and Panicum maximum and the straw formation in a no-tillage system
}

\author{
Sobressemeadura de soja com Urochloa brizantha e Panicum \\ maximum e formação de palha para o sistema de plantio direto
}

\author{
Núbia Maria Correia ${ }^{1 *}$; Leonardo José Petean Gomes ${ }^{2}$
}

\begin{abstract}
The objective of this study was to evaluate the soybean oversowing with braquiarão (Urochloa brizantha $\mathrm{cv}$. Marandu) and colonião (Panicum maximum cv. Aruana) and the capacity of these forage crops to produce dry mass during the fall-winter-spring period. Two experiments, one for each forage species, were conducted in field conditions in the 2011/2012 season and were repeated in 2012/2013. The experimental set-up was arranged in a randomized block design with four repetitions in a $2 \times 5$ factorial. The soybean oversowing was studied in the development stages $R_{6}$ and $R_{8}(2011 / 2012)$ or $R_{5}$ and $R_{8}(2012 / 2013)$ with braquiarão or colonião grass in five seed amounts $(200,400,600,800$ and 1000 points of cultural value $-\mathrm{PCV}=$ seeds amount $\mathrm{x}$ culture value). In both seasons, the braquiarão oversowing at soybean stages $\mathrm{R}_{5}$ and $\mathrm{R}_{6}$ resulted in higher dry mass production, when compared to stage $\mathrm{R}_{8}$. Additionally, the amount of 600 seeds PCV was sufficient to obtain an excellent percentage of soil cover $(>95 \%)$, in addition to the satisfactory number of plants per $\mathrm{m}^{2}$ and the dry mass production. On the other hand, independent of the soybean development stage in the oversowing moment, colonião was not promising for use in this sowing type because its low stand and irregular soil covering, even at the higher seed amounts.
\end{abstract}

Key words: Glycine $\max$ L. Forage grasses. Agriculture-cattle activity integration.

\section{Resumo}

Objetivou-se com esse trabalho estudar a sobressemeadura da cultura da soja com braquiarão (Urochloa brizantha cv. Marandu) e colonião (Panicum maximum cv. Aruana) e a capacidade de produção de matéria seca pelas forrageiras no período de outono-inverno-primavera. Dois experimentos, um para cada espécie, foram desenvolvidos em campo, no ano agrícola 2011/2012; e repetidos em 2012/2013. $\mathrm{O}$ delineamento experimental foi o de blocos ao acaso, com quatro repetições, em esquema fatorial $2 \mathrm{x}$ 5. Foi estudada a sobressemeadura da soja nos estádios de desenvolvimento $R_{6}$ e $R_{8}$ (em 2011/2012) ou $\mathrm{R}_{5}$ e $\mathrm{R}_{8}$ (em 2012/2013) com braquiarão ou colonião em cinco quantidades de sementes (200, 400, 600, 800 e 1000 pontos de valor cultural $-\mathrm{PVC}=$ quantidade de sementes $\mathrm{x}$ valor cultural). Nos dois anos agrícolas, a sobressemeadura de braquiarão nos estádios $\mathrm{R}_{5}$ e $\mathrm{R}_{6}$ da soja resultou em maior produção de matéria seca comparados ao estádio $\mathrm{R}_{8}$. Além disso, a quantidade de $600 \mathrm{PVC}$ de sementes foi suficiente para a obtenção de excelente porcentagem de cobertura do terreno ( $>95 \%)$, além de número de plantas por $\mathrm{m}^{2}$ e produção de matéria seca satisfatórios. Por outro lado, independentemente do estádio de desenvolvimento da soja no momento da sobressemeadura, o colonião não foi promissor para uso nessa modalidade de semeadura, devido ao baixo estande e cobertura desuniforme do terreno, mesmo na maior quantidade de sementes.

Palavras-chave: Glycine max L. Gramíneas forrageiras. Integração agricultura-pecuária.

\footnotetext{
${ }^{1}$ Pesquisadora, Embrapa Hortaliças, Brasília, DF, Brasil. E-mail: nubia.correia@embrapa.br

${ }^{2}$ Discente do Curso de Mestrado do Programa de Pós-Gradução em Agronomia - Produção Vegetal, UNESP, Câmpus de Jaboticabal, SP, Brasil. E-mail: leo_pgomes@hotmail.com

* Author for correspondence
} 


\section{Introduction}

In the agricultural areas of most parts of São Paulo State and Central Brazil, there was low straw production during the fall-winter-spring season because of the unfavorable climatic conditions and low hydric availability characterized by the dry winter. Consequently, most areas remained fallow during seven months of the year and with a low level of plant cover (BARDUCCI et al., 2009). One option to address this problem is soybean oversowing, which consists in the aerial implantation of cover crops during the stages $\mathrm{R}_{5}$ to $\mathrm{R}_{7}$ (PACHECO et al., 2008, 2013; SILVA et al., 2013).

The success of this technology depends on a number of factors including the climatic conditions before the sowing until ten days after the plants emerge, the germination capacity, the growth of cover plants on the soil surface, the degree of defoliation and the degree of direct light incidence over the soil surface (PACHECO et al., 2008, 2013). The cover promoted by the soybean leaves that fall over the cover plant seeds is essential to their emergence because they increase their contact with the soil and consequently help to protect against seed dehydration in case of hydric stress (ALTMANN, 2010).

Additionally, to consolidate this technique, the evaluation and selection of species that are welladapted to the intercropping do not cause damage against the main crop, are tolerant to hydric stress, produce high mass to cover the soil and, if possible, are suitable for use as forage (LARA-CABEZAS, 2004; PERIN et al., 2004; PACHECO et al., 2008).

Species of the genera Urochloa and Panicum show promise for utilization in oversowing because they present high tolerance against water stress and are able to absorb nutrients from the deeper soil layers, which enable development in environmental conditions that are unfavorable to most grain and soil cover crops (BARDUCCI et al., 2009). The utilization of these species as cover crops during the off-season (fall/winter) in the Cerrado, when the precipitation is reduced and the focus is the accumulation of dry mass, is highly promising as pasture or for straw formation in a no-tillage system (CORREIA et al., 2013). For straw formation, plants should be eliminated by mechanical or chemical methods before the grain crop is sown (spring/ summer).

There are several benefits to utilizing the oversowing technique in soybean crops, including using forage species for straw formation in a notillage system or for cattle feed during the dry season. However, some issues need to be addressed, such as the ideal amount of seeds, the soybean phenologic stage at the time of oversowing and the utilization of different forage species, such as the genera Urochloa and Panicum. The amount of seeds must be adjusted for each cover species and specified based on their pure live seed index, which is expressed in points of cultural value $(\mathrm{PCV}=$ seeds amount $\mathrm{x}$ culture value) to facilitate information diffusion. In this context, São Paulo State, Northeast region presents difficulties for the establishment of crops in the fall-winter season because of the hydric deficit, which influences the straw formation in a no-tillage system.

The objective of this study was to evaluate soybean oversowing with braquiarão (Urochloa brizantha cv. Marandu) and colonião (Panicum maximum $\mathrm{cv}$. Aruana) and the dry mass production capacity of these plants during the fall-winter-spring season.

\section{Material and Methods}

Two field experiments, one using brachiarão and the other colonião grass, were conducted between October/2011 - October/2012 in an experimental area from UNESP - Jaboticabal, SP, Brazil and were repeated in another locale in the same experimental area between November-2012 October/2013.

For each experiment, the experimental set-up was arranged in a randomized block design with 
four repetitions in a 2 x 5 factorial. The soybean oversowing was studied in the development stages $\mathrm{R}_{6}$ and $\mathrm{R}_{8}(2011 / 2012)$ or $\mathrm{R}_{5}$ and $\mathrm{R}_{8}(2012 / 2013)$ with braquiarão or colonião grass in five seed amounts (200, 400, 600, 800 and 1000 PCV).

The soybean (cvs. Dow 5 D 660 RR, in the first year, and SYN $9070 \mathrm{RR}$, in the second) was sowed in 10/27/ 2011 and 11/05/2012, with direct sowing at a depth of $5 \mathrm{~cm}, 45 \mathrm{~cm}$ distance between rows and 21 seeds per meter. The fertilization protocol consisted of $300 \mathrm{~kg} \mathrm{ha}^{-1}$ of a 02-20-20 formula. A liquid inoculant (0.24 L c.p. ha $\left.{ }^{-1}\right)$ and the insecticide clorpirifos $\left(0.48 \mathrm{~kg}\right.$ a.i. $\left.\mathrm{ha}^{-1}\right)$ were applied in the sowing furrow.

The plots were $4.05 \mathrm{~cm}$ wide and $7 \mathrm{~m}$ long, with seven central rows $5 \mathrm{~m}$ long as the utilized area, totaling $18.9 \mathrm{~m}^{2}$.

For weed control, the herbicide glyphosate (1.0 kg a.e. $\left.\mathrm{ha}^{-1}\right)$ was sprayed post-emergence, and insecticides and fungicides sprayers were used when necessary.

The soybean plants were in the development stages $\mathrm{R}_{6}$ (pods with $100 \%$ grain-filling and green leaves) and $\mathrm{R}_{8}$ (the beginning of $50 \%$ defoliation) in February 10 and 23/2012, respectively. The plants were in $\mathrm{R}_{5}$ (most pods between $75 \%$ and $100 \%$ gain-filling) and $\mathrm{R}_{8}$ (begin to $50 \%$ defoliation) in $01 / 25$ and $02 / 19 / 2013$, respectively, when the forage species manual broadcast seeding was performed, according the seed amount to be tested.

In the first year, the braquiarão seeds presented $79.0 \%$ germination, $97.1 \%$ purity and a culture value of 76.7 , while the colonião seeds showed $81 \%$ germination, $99.1 \%$ purity and 80.27 pure live seed. In the second year, the values were $81.0 \%$ germination, $98.1 \%$ purity and 79.46 culture value for the braquiarão seeds, and $89.0 \%$ germination, $99.8 \%$ purity and 88.82 pure live seed for colonião. The seed amount $\left(\mathrm{kg} \mathrm{ha}^{-1}\right)$ is the relation between the desired PCV and the culture value. For both species, pelleted seeds were used.

The daily rainfall during $01 / 20$ to $03 / 10 / 2012$ and $01 / 15$ to $03 / 25 / 2013$ is shown in Figure 1 . The dry period registered between $01 / 29$ and $02 / 07$ made the oversowing of forage species in the soybean $\mathrm{R}_{5}$ stage impossible in the first year. Appropriate climatic conditions, mainly precipitation before and after the oversowing, are essential to the plants emergence and establishment. For this reason, we opted to wait for the best occasion of soil humidity.

The soybeans were harvested using a selfpropelled harvester, with the straw being returned to the plots. The harvesting was conducted on 03/10/2012, at 29 and 16 days after the oversowing (DAO) in the $\mathrm{R}_{6}$ and $\mathrm{R}_{8}$ soybean development stages, respectively, and on 03/05/2013, at 39 and 14 days after the oversowing (DAO) in the $\mathrm{R}_{6}$ and $\mathrm{R}_{8}$ soybean development stages, respectively. The cut height of the soybean plants was 8 to $10 \mathrm{~cm}$ above the soil surface.

In both experimental years, the forage plants stand was quantified at $35 \mathrm{DAO}$. The number of plants in a $5.4 \mathrm{~m}^{2}$ area was counted, corresponding to $0.9 \mathrm{~m}$ width $\mathrm{x} 6 \mathrm{~m}$ length, and analyzed in the utilized area of the plot. At 233 and 244 days after the soybean harvest (DAH), on 10/29/2012 and $11 / 05 / 2013$, respectively during the pre-sowing of the subsequent crop, the soil cover by forage plants was visually evaluated (by only one evaluator who was the same in both seasons) using a scale from 0 to $100 \%$, where zero represents the absence of plants and 100 represents the total area covered by the forage plant. On these same dates, plant shoots were randomly collected in two areas of $0.45 \mathrm{~m}^{2}$ inside of the utilized area of each plot to determine the plant shoot dry mass.

The results were submitted to the F-test for the analysis of variance. The effects of the oversowing seasons, when significant, were compared by the Tukey test at a 5\% significance level, and the seed amounts were compared by the data polynomial adjustment. The interactions, when significant, were compared by the Tukey test at 5\% probability for the oversowing seasons, and by the data polynomial adjustment for the seed amounts. 
Figure 1. Daily values for precipitation registered from $01 / 20$ to $03 / 10 / 2012$ (a) and from $01 / 15$ to $03 / 25 / 2013$ (b). Source: Agroclimatologic Station of Ciências Exatas Department of FCAV/UNESP localized to 2.0 and $0.5 \mathrm{~km}$ from experimental areas in the $1^{\text {st }}$ and $2^{\text {nd }}$ year, respectively.

(a)

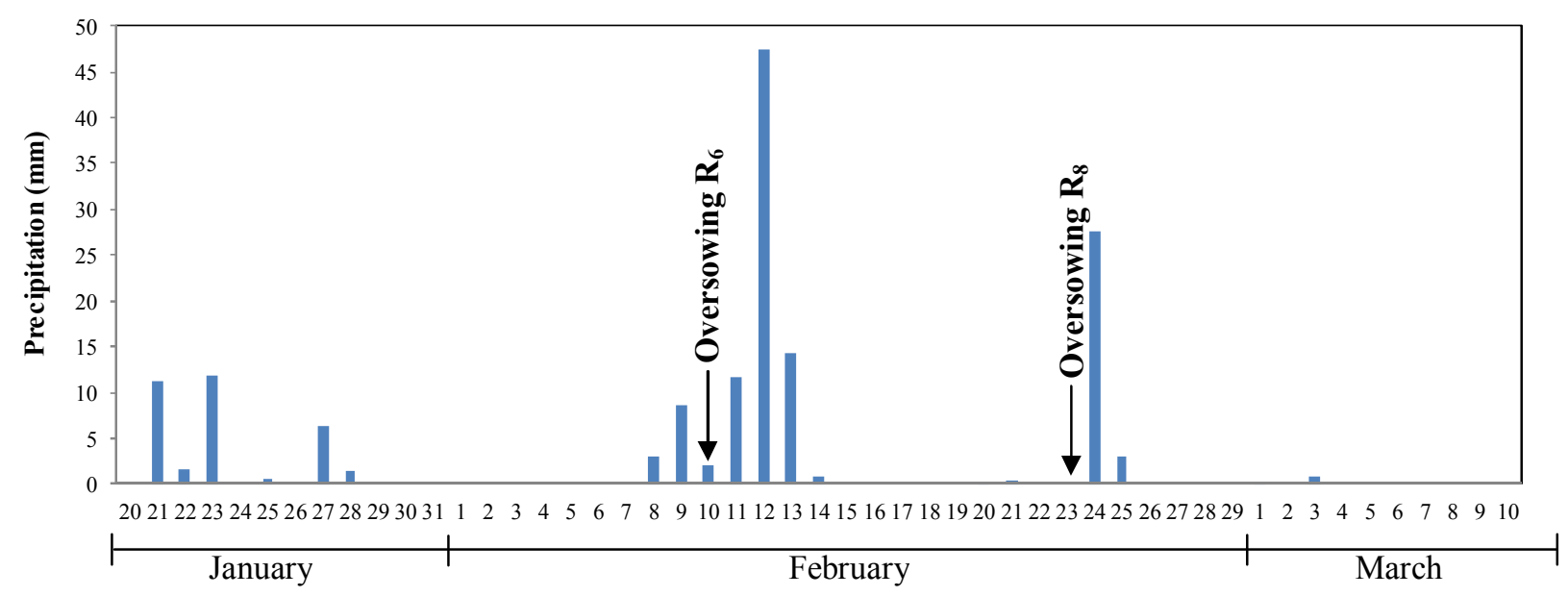

(b)

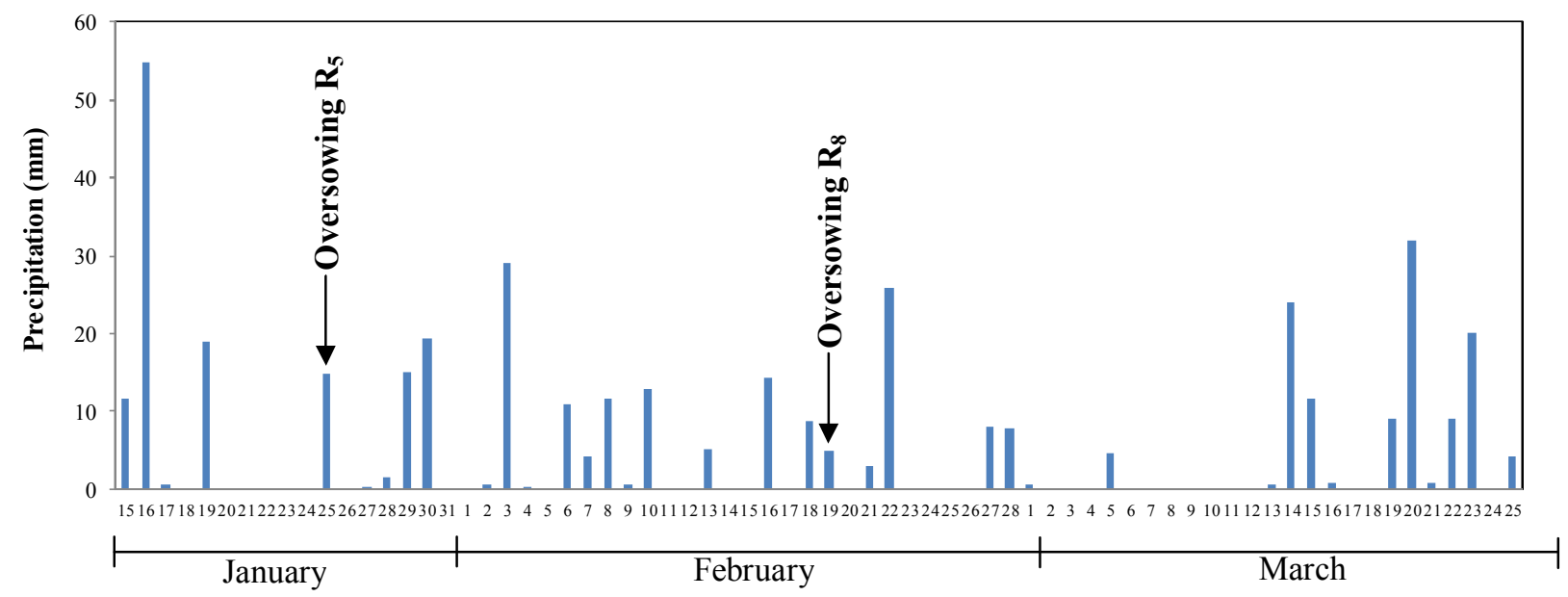

\section{Results and Discussion}

Regarding the experiments of soybean oversowing with braquiarão, the interaction of seed amount $\mathrm{x}$ development stage was not significant for any evaluated characteristic in both study years (Table 1).
The soybean developmental stages significantly affected the number of emerged plants in the second year and the shoot dry mass in both study years. The braquiarão oversowing in the $\mathrm{R}_{6}$ and $\mathrm{R}_{5}$ soybean development stages resulted in higher dry mass production in both seasons and higher plant density in the second year, when compared to oversowing in the $\mathrm{R}_{8}$ stage (Table 2). 
Table 1. Results of $\mathrm{F}$ test of analysis of variance for braquiarão plant density at 35 days after the oversowing (DAO) in the soybean crop, over the soil cover by the forage and plants dry mass at 233 and 244 days after the soybean harvest (DAH), respectively, for the first and second year.

\begin{tabular}{lcccccc}
\hline \multirow{2}{*}{ Variation Sources } & \multicolumn{2}{c}{ Density } & \multicolumn{2}{c}{ Cover } & \multicolumn{2}{c}{ Dry mass } \\
\cline { 2 - 6 } & $\mathbf{1}^{\text {st }}$ year & $\mathbf{2}^{\text {nd }}$ year & $\mathbf{1}^{\text {st }}$ year & $\mathbf{2}^{\text {nd }}$ year & $\mathbf{1}^{\text {st }}$ year & $\mathbf{2}^{\text {nd }}$ year \\
\hline Seed amount & $12.29^{* *}$ & $12.74^{* *}$ & $16.84^{* *}$ & $13.46^{* *}$ & $3.84^{*}$ & $4.58^{* *}$ \\
Development stage & 0.72 & $7.22^{*}$ & 3.25 & 1.71 & $13.99^{* *}$ & $12.82^{* *}$ \\
Seeds x Stage & 0.20 & 1.09 & 2.24 & 1.76 & 2.42 & 1.90 \\
CV $(\%)$ & 29.75 & 25.72 & 5.91 & 5.81 & 21.36 & 20.91 \\
\hline
\end{tabular}

**, * Significant at $1 \%$ and $5 \%$ of probability, respectively, by F-test of the analysis of variance.

Table 2. Braquiarão shoot dry mass at 233 and 244 days after soybean harvest, in the 2011/2012 and 2012/2013 seasons, over the plant density in the 2012/2013 season, at 35 days after the forage oversowing in two soybean development stages.

\begin{tabular}{cccc}
\hline \multirow{2}{*}{ Development stages } & \multicolumn{2}{c}{ Dry mass $\left(\mathbf{t} \mathbf{~ h a}^{-\mathbf{1}}\right)$} & Density $\left.\mathbf{~ p l . ~ 5 . 4} \mathbf{~ m}^{-\mathbf{2}}\right)$ \\
\cline { 2 - 4 } & $\mathbf{1}^{\text {st }}$ year & $\mathbf{2}^{\text {nd }}$ year & $\mathbf{2}^{\text {nd }}$ year \\
\hline $\mathrm{R}_{6} / \mathrm{R}_{5}$ & $10.04 \mathrm{a}^{(1)}$ & $12.61 \mathrm{a}$ & $15.12 \mathrm{a}$ \\
$\mathrm{R}_{8}$ & $7.79 \mathrm{~b}$ & $9.73 \mathrm{~b}$ & $10.20 \mathrm{~b}$ \\
$\mathrm{LSD}$ & 1.24 & 1.59 & 3.76 \\
\hline
\end{tabular}

(1) $\mathrm{R}_{6}$ and $\mathrm{R}_{5}$ in the first and second year, respectively. ${ }^{(2)}$ Means followed by the same letter indicate no significant difference by the Tukey test at $5 \%$ of probability.

There was a significant effect of the braquiarão seed amount for all the evaluated parameters. The braquiarão stand increased linearly with the increase in the seed amount in both seasons (Figure 2). However, even with $1000 \mathrm{PCV}$, the plant density did not exceed 5.7 plants per $\mathrm{m}^{2}$. Kluthcouski and Aidar (2003) recommended a minimum of 6 plants per $\mathrm{m}^{2}$ of Brachiaria species for their establishment as cover plants in the Cerrado region. In this study, to obtain sufficient plant density, an oversowing of 1046 and 1470 seeds PCV was necessary, for the first and second year, respectively.

Pacheco et al. (2008), evaluating the oversowing of 768 PCV Brachiaria brizantha seeds in the $\mathrm{R}_{7}$ soybean stage, obtained 10.58 plants per $\mathrm{m}^{2}$, when the oversowing was performed on January 30 . The high rain volume (approximately $200 \mathrm{~mm}$ ) in the first 30 days after the oversowing could contribute to the higher plant emergence, compared to this study. The climatic conditions, mainly the rainfall before the oversowing and until ten days after the plant emergence, are essential to the plants' establishment. Thus, after the braquiarão sowing at $\mathrm{R}_{6}$ and $\mathrm{R}_{8}$, the accumulated precipitation in the next 30 days was 108.4 and $58.5 \mathrm{~mm}$ (first year) and 183.5 and 134.0 (second year), respectively. This difference in the rain volume influenced the oversown forage emergence in the two soybean development stages.

Regarding the percentage of soil cover by the plants for the two years, the best data adjustment was obtained in polynomial form, with cover higher than $90 \%$ from $400 \mathrm{PCV}$. Even in plots with low plant density per $\mathrm{m}^{2}$, there was good soil cover by braquiarão. However, in inadequate stand conditions, the formation of more dense clumps occurs that are associated to the cespitose and erect growth plant habits, which can inhibit the sowing of the subsequent crop by direct sowing because of the difficulty presented by the cut clumps to the incorporation of seeds by the planter. 
Figure 2. Braquiarão plant density at 35 days after the oversowing with different amounts of seed, over the percentage of soil cover by plants and shoot dry mass at 233 and 244 days after harvest, in the 2011/2012 and 2012/2013 seasons.
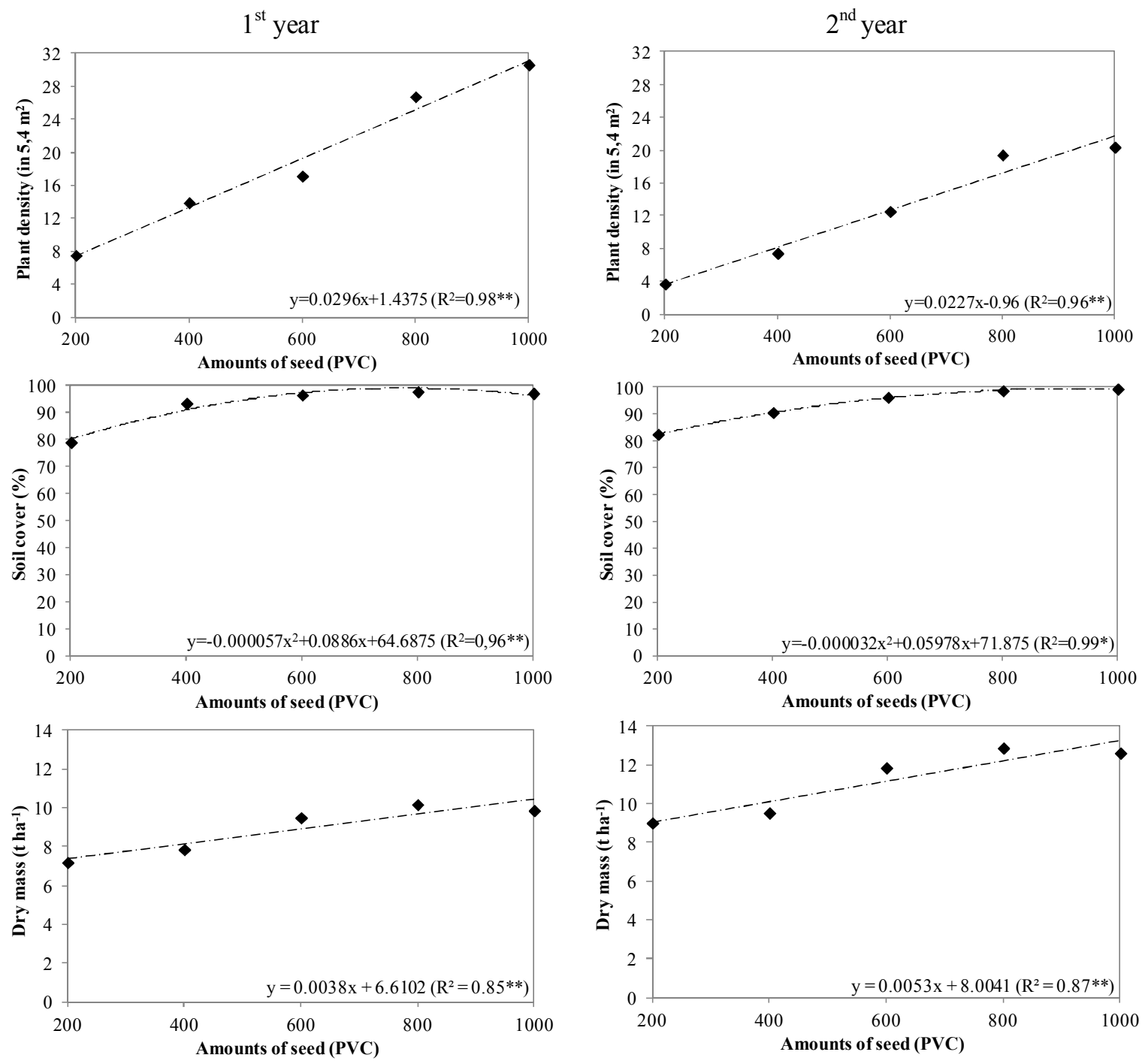

The forage dry mass production increased linearly with the increase of the seed amount in both years. The values oscillated from 7.4 to $10.5 \mathrm{t} \mathrm{ha}^{-1}$ in the first year and 9.1 to $13.3 \mathrm{tha}^{-1}$ in the second, respectively, for the seed amounts of 200 to 1000 PCV. In another study, the $B$. brizantha oversowing (768 seeds $\mathrm{PCV}$ ) in the soybean $\mathrm{R}_{7}$ stage promoted the maintenance of up to $9.9 \mathrm{t} \mathrm{ha}^{-1}$ of straw over the soil, until the soybean sowing in the next season (PACHECO et al., 2008).

For the experiments with the soybean oversowing with colonião, the interaction between the seed

amount $\mathrm{x}$ development stages was not significant to any evaluated parameter, in either of the years (Table 3).

The soybean developmental stages significantly influenced the plant density in the second year and the cover percentage in the first. When the oversowing was performed in the $\mathrm{R}_{6}$ stage, there was more soil covered than in the $\mathrm{R}_{8}$ stage (Table 4). In the second year, with the oversowing in the $\mathrm{R}_{5}$ stage, there was lower colonião emergence, when compared to the $\mathrm{R}_{8}$ stage. 
Table 3. Results of $F$ test of analysis of variance for colonião plant density at 35 days after the oversowing (DAO) in the soybean crop, over the soil cover by the forage and plants dry mass at 233 and 244 days after the soybean harvest (DAH), respectively, for the first and second year.

\begin{tabular}{lcccccc}
\hline \multirow{2}{*}{ Variation Sources } & \multicolumn{2}{c}{ Density } & \multicolumn{2}{c}{ Cover } & \multicolumn{2}{c}{ Dry mass } \\
\cline { 2 - 6 } & $\mathbf{1}^{\text {st }} \mathbf{y e a r}$ & $\mathbf{2}^{\text {nd }}$ year & $\mathbf{1}^{\text {st }}$ year & $\mathbf{2}^{\text {nd }}$ year & $\mathbf{1}^{\text {st }}$ year & $\mathbf{2}^{\text {nd }}$ year \\
\hline Seed amount & $2.53^{*}$ & $11.10^{* *}$ & $8.64^{* *}$ & $7.87^{* *}$ & $5.39^{* *}$ & $3.78^{*}$ \\
Development stage & 1.35 & $24.98^{* *}$ & $8.89^{* *}$ & 3.65 & 3.75 & 1.67 \\
Seeds x Stage & 1.07 & 0.68 & 0.62 & 0.52 & 1.87 & 0.58 \\
CV $(\%)$ & 42.23 & 34.32 & 26.32 & 25.58 & 36.54 & 39.27 \\
\hline
\end{tabular}

**, * Significant at $1 \%$ and $5 \%$ of probability, respectively, by F-test of the analysis of variance.

Table 4. Percentage of soil cover by colonião plants at 233 days after the soybean harvest in the 2011/2012 season, over the plants density, in the 2011/2012 season, at 35 days after the forage oversowing in two soybean development stages.

\begin{tabular}{ccc}
\hline \multirow{2}{*}{ Development stages } & Cover $\mathbf{( \% )}$ & Density $\left(\mathbf{p l . ~ 5 . 4} \mathbf{~ m}^{\mathbf{2}}\right)$ \\
\cline { 2 - 3 } $\mathrm{R}_{6}$ & $\mathbf{1}^{\text {st }}$ year & $\mathbf{2}^{\text {nd }}$ year \\
$\mathrm{R}_{8}$ & $62.88 \mathrm{a}^{(1)}$ & $4.88 \mathrm{~b}^{(1)}$ \\
$\mathrm{LSD}$ & $49.00 \mathrm{~b}$ & $10.14 \mathrm{a}$ \\
\hline
\end{tabular}

(1) $\mathrm{R}_{6}$ and $\mathrm{R}_{5}$ in the first and second year, respectively. ${ }^{(2)}$ Means followed by the same letter indicate no significant difference by the Tukey test at $5 \%$ probability.

There was a significant effect for the colonião seed amount for all the evaluated characteristics. In both seasons, the colonião density, the percentage of soil cover and the dry mass production increased with the increase of the seed amount, with linear or polynomial data adjustment (Figure 3 ). The increase of the dry mass varied from 4.6 to $10.2 \mathrm{tha}^{-1}$ and the soil cover from 38 to $74 \%$, in the first year; for the next year the values were from 7.1 to $13.5 \mathrm{t} \mathrm{ha}^{-1}$ and from 40 to $77 \%$, respectively, for the seed amounts of 200 to $1000 \mathrm{PCV}$.

Considering the difficulty of establishing crops during the fall-winter season in the São Paulo North region because of the hydric deficit, the colonião plants dry mass production was striking. The distribution of the vegetable residue over the soil was irregular because even with $4.6 \mathrm{t} \mathrm{ha}^{-1}$, which is satisfactory for local conditions, the straw was concentrated only in $38 \%$ of the plot while the remaining area was uncovered.

The colonião plant is tall, cespitose and form A planta de colonião é de porte alto, cespitosa e forma dense clumps (KISSMANN, 1997). These characteristics make it difficult to create soil cover, in the case of mainly broadcast seeding without seed incorporation or soil turning - conditions that demand high seed amounts to obtain a high plant density per area and better space occupation by the plants. Based on the soil cover percentage in pre-sowing of the subsequent crop, in a colonião oversowing of a soybean crop, approximately 1300 seeds PCV would be necessary to cover at least $90 \%$ of the soil. This amount of seed is not viable economically. 
Figure 3. Colonião plant density 35 days after the oversowing with different amounts of seed, over the percentage of soil cover by plants and shoot dry mass at 233 and 244 days after harvest, in the 2011/2012 and 2012/2013 seasons.
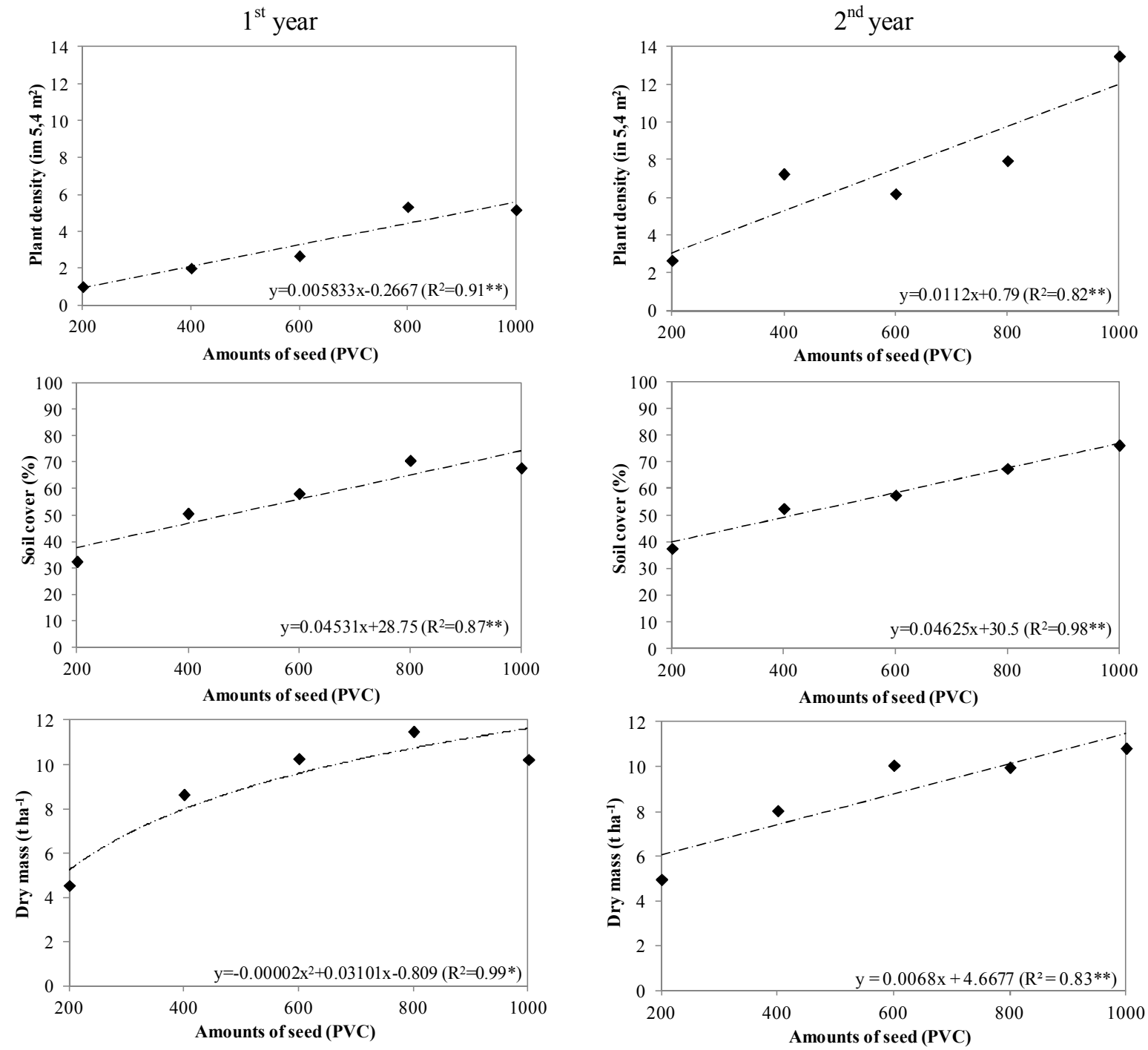

The plant density, even with the oversowing of 1000 seeds PCV, was unimpressive, reaching the maximum of 2.2 plants per $\mathrm{m}^{2}$ (at $35 \mathrm{DAO}$, in the second year). However, the stand was higher in the 2011/2012 season and achieved 1.0 plant per $\mathrm{m}^{2}$ when 1000 seed PCV was used. Simulating the colonião (P. maximum cv. Tanzânia) oversowing in pots, Pacheco et al. (2010) reported that when seeds were deposited on the soil surface and covered with soybean leaves and a few layers of soil, the forage emergence was similar to seeding at $1 \mathrm{~cm}$ soil depth. These data do not corroborate those obtained in the

current study because the colonião emergence when oversown in the soybean crop was unsatisfactory.

There was higher colonião emergence in the second year; however, the soil covered at $244 \mathrm{DAH}$ did not interfere with the plants' increase. This result can be explained by the low rainfall between $04 / 14$ to $05 / 26 / 2013$ (Figure 4 ) and to the growth habits of colonião, which requires a more substantial increase in the plant density. There was less water available before and after the oversowing, but, during the plant establishment after the soybean harvest, the rainfall was more regular than in the second year. 
Figure 4. Monthly mean values for the minimum and maximum temperature, over the monthly total precipitation, registered between October/2012 and October/2013.

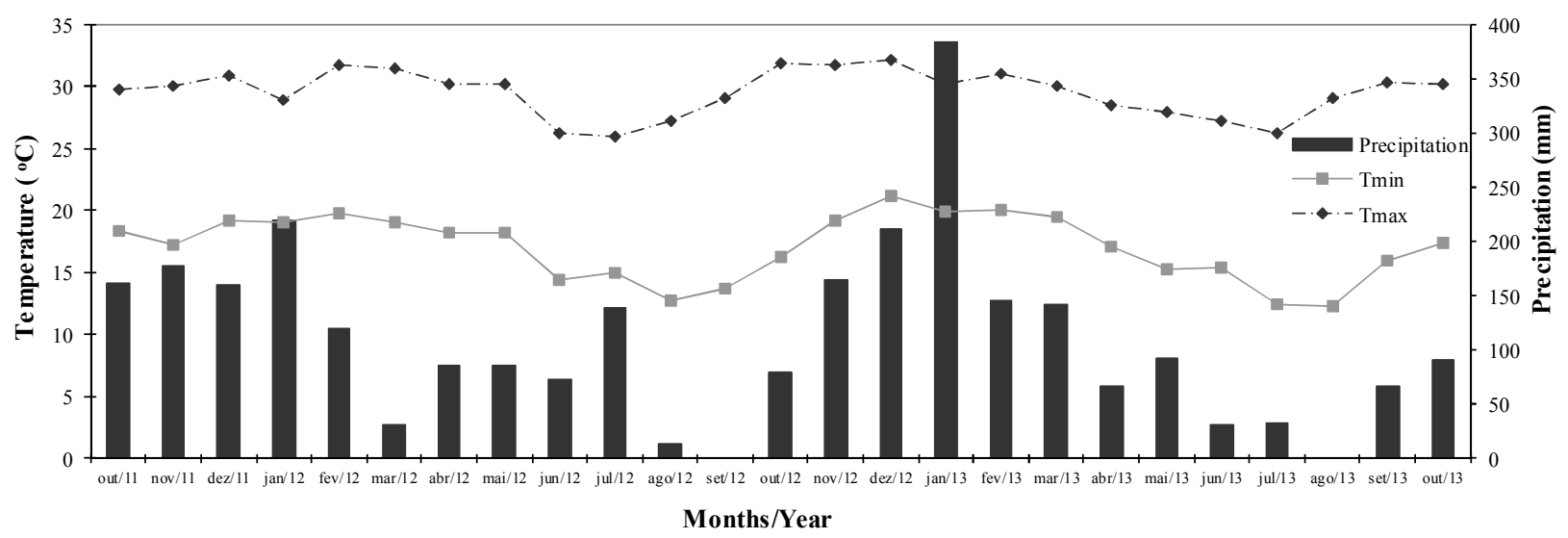

Source: Agroclimatologic Station of Ciências Exatas Department from FCAV/UNESP localized to 2.0 and $0.5 \mathrm{~km}$ from the experimental areas in the $1^{\text {st }}$ and $2^{\text {nd }}$ year, respectively.

Based on the obtained results, it can be concluded that the braquiarão ( $U$. brizantha $\mathrm{cv}$. Marandu) oversowing at soybean stages $\mathrm{R}_{5}$ and $\mathrm{R}_{6}$ resulted in higher dry mass production when compared to stage $\mathrm{R}_{8}$. Additionally, the amount of 600 seeds PCV was sufficient to obtain a soil cover percentage higher than $95 \%$, which exceeded the satisfactory number of plants per $\mathrm{m}^{2}$ and the dry mass.

Independent of the soybean development stage at the time of oversowing, colonião o colonião (. maximum cv. Aruana) was not promising for use in this type of sowing because of its low height and irregular soil cover, even at the higher seed amounts (1000 PCV).

\section{Acknowledgements}

The authors acknowledge the Fundação de Amparo à Pesquisa do Estado de São Paulo (FAPESP) for its support.

\section{References}

ALTMANN, N. Sobressemeadura de pastagens. [S.1.: s.n], 2010. Disponível em: <http://www.sigmaac.com. br/sites/1200/1280/00000025.pdf $>$. Acesso em: 29 jun. 2010 .
BARDUCCI, R. S.; COSTA, C.; CRUSCIOL, C. A. C.; BORGHI, E.; PUTAROV, T. C.; SARTI, L. M. N.; Produção de Brachiaria Brizantha e Panicum Maximum com milho e adubação nitrogenada. Revista Archivos de Zootecnia, Córdoba, v. 58, n. 222, p. 211-222, 2009.

CORREIA, N. M.; LEITE, M. B.; FUZITA, W. E. Consórcio de milho com Urochloa ruziziensis e os efeitos na cultura da soja em rotação. Bioscience Journal, Uberlândia, v. 29, n. 1, p. 65-76, 2013.

KISSMANN, K. G. Plantas infestantes nocivas. 2. ed. São Paulo: BASF, 1997. 825 p.

KLUTHCOUSKI, J.; AIDAR, H. Implantação, condução e resultados obtidos com o sistema Santa Fé. In: KLUTHCOUSKI, J.; STONE, L. F.; AIDAR, H. (Ed.). Integração lavoura-pecuária. Santo Antônio de Goiás: EMBRAPA Arroz e Feijão, 2003. p. 407-459.

LARA-CABEZAS, W. A. R. Sobressemeadura com sementes de milheto revestidas no Triângulo Mineiro MG: estudo preliminar. Revista Plantio Direto, Passo Fundo, v. 79, n. 1, p. 16-18, 2004.

PACHECO, L. P.; MONTEIRO, M. M. S.; SILVA, R. F.; SOARES, L. S.; FONSECA, W. L.; NÓBREGA, J. C. A.; PETTER, F. A.; ALCÂNTARA NETO, F.; OSAJIMA, J. A. Produção de fitomassa e acúmulo de nutrientes por plantas de cobertura no cerrado piauiense. Bragantia, Campinas, v. 72, n. 3, p. 237-246, 2013

PACHECO, L. P.; PIRES, F. R.; MONTEIRO, F. P.; PROCÓPIO, S. O.; ASSIS, R. L.; CARMO, M. L.; PETTER, F. A. Desempenho de plantas de cobertura 
em sobressemeadura na cultura da soja. Pesquisa Agropecuária Brasileira, Brasília, v. 43, n. 7, p. 815-823, 2008.

PACHECO, L. P.; PIRES, F. R.; MONTEIRO, F. P.; PROCÓPIO, S. O.; ASSIS, R. L. de; PETTER, F. A. Profundidade de semeadura e crescimento inicial de espécies forrageiras utilizadas para cobertura do solo. Ciência e Agrotecnologia, Lavras, v. 34, n. 5, p. 12111218, 2010.
PERIN, A.; SANTOS, R. H. S.; URQUIAGA, S.; GUERRA, J. G. M.; CECON, P. R. Produção de fitomassa, acúmulo de nutrientes e fixação biológica de nitrogênio por adubos verdes em cultivo isolado e consorciado. Pesquisa Agropecuária Brasileira, Brasília, v. 39, n. 1, p. 35-40, 2004.

SILVA, W. B.; PETTER, F. A.; LIMA, L. B.; ANDRADE, F. R. Desenvolvimento inicial de Urochloa ruziziensis e desempenho agronômico da soja em diferentes arranjos espaciais no cerrado Mato-Grossense. Bragantia, Campinas, v. 72, n. 2, p. 146-153, 2013. 